\title{
Investment Pattern and Legal Provisions
}

\section{in India}

\author{
Nidhi Khanna ${ }^{1}$ \\ ${ }^{1}$ Faculty of Commerce, Banaras Hindu University, \\ Varanasi - 221005, Uttar Pradesh, India
}

\begin{abstract}
The present paper is an attempt to identify the investment opportunities in India to meet the responsibilities after retirement and to enjoy leisure without short of funds. An idle cash lying in account is a waste of money until it is best utilized and invested in portfolio opportunities to earn return from these investments. India has diversified vehicle for investments and social security schemes like employees provident fund, pension fund, public provident fund, mutual funds, real estate investment opportunities, fixed and recurring account and many more. The primary objective of this paper is to identify in brief defined contribution from employers and investment opportunities of employees from secondary sources of information.
\end{abstract}

Keywords- Employees Provident Fund, Fixed deposit, Mutual Funds, Portfolio Investment

\section{Introduction}

Since the eve of independence, India has witnessed a sustainable growth in the economy due to enormous structural changes in banking and financial market still, evidence from the studies clearly portrays the lack of financial literacy and awareness among the most allied and educated. For any developing economy to flourish, it necessitates to have in-depth knowledge for investment, risk and return for effective circular flow of an economy. The emerging concept of financial inclusion by the government can only be strengthened only if the conducive environment is created for the investors. The principle feature of any investment policy is liquidity to fulfill demand and need as and when required by fixed income group while the perseverance and consistency of investment is the idle feature of an investor. The tendency of people has changed from "spend the money whatever is left, save" to "save and invest, then spend". There are numerous mandatory and non mandatory investment opportunities available to investors to park their savings based on riskreturn characteristics of investors. However, government of India is making continuous effort to promote saving of government employees in their working life so that they have handful amount during their retirement and can lead a peaceful life.

The investment pattern of investors solely depends upon the risk absorbing capacity of an individuals .For long term investment bonds are preferred while the risky investors as a rule of thumb go for equity. A number of theories like Merton's continuous time model, Markowitz model of portfolio define the life cycle finance concept depending upon the life expectancy and horizon of work. A proper management of funds is equally important as earnings from different sources be it a personal savings from regular income, defined contribution from pension or provident fund, wealth transferred from ancestors, gifts from ancestors or any.

\section{Objectives of the Study}

The study incorporates the following objectives-

- To examine present legal provisions of employment

- To study different investment opportunities in current economic scenario

\section{Investment and Legal Provision}

Employees Provident Fund- Employees Provident fund is one of the largest organization in terms of beneficiary and asset investment working under central board of direct taxes headquarter at Bhavishya Nidhi Bhavan, New Delhi, India implemented in the year 1952. EPF scheme is a completely tax free mandatory contribution of both employer and a employee at the rate $12 \%$ of the basic pay. The contribution of an employee is $12 \%$ of their basic pay together with employer contribution $3.67 \%$ out of $12 \%$ goes to EPFO scheme, while the remaining contribution $8.33 \%$ of employer is diversified and invested into Pension scheme. Recently Government of India has made it mandatory to be linked to UAN and PAN number. 
The major benefit of this scheme is that it can be used by employees during the time of emergencies during their employment and after retirement for maintaining standard of living (Shekhar, R, 2013).

Gratuity- Gratuity is a compulsory payment made by an employer to employee for rendering continuous service for not less than 5 years. Gratuity Act enforced in the year 1972, for an employer employing more than 10 employees. Payment can be done on the occasion of superannuation, retirement, in form of 15 days wages for a continuous service rendered (Shekhar, $\mathrm{R}, 2013)$. It is generally offered for post retirement benefit to provide financial protection to employee during old age because of incapacity to earn (Rajora,V, 2010).

National Pension System- Pension scheme has been initiated by Government of India for an unorganized sector to promote saving and investment in middle-low income group, in form of a monthly contribution by workers especially for those who do not have access to banking. The immediate benefit offered by NPS is that it improves investment choices by bringing about transparency at low cost. The transaction in NPS is monitored by Pension fund Managers. Only the employer and the government are eligible to make contribution in Pension system that makes it clearly different from Provident fund (Thomas, 2014).

\section{Data Collection}

The present paper is descriptive, suggesting the conventional and latest method of investment and financial decision in Indian perspective .Secondary sources of information is used to collect information such as Reserve bank of India bulletin, published paper, journal, articles and websites.

\section{Literature Review}

(Gopi G, Priyanka D and Preetha R, 2018), in their study observed a significance relationship between annual savings and rate of return, percentage of investment and knowledge level of investment. The study identifies the main reason of investment is earn return and tax savings. Most of the savings are done to meet individual's personal as well as family expenses such as daughter's marriage, children education, medical treatment. It has been observed that $100 \%$ employers are aware of Life insurance, Mutual fund, Provident Fund, Fixed deposit while less are aware of FOREX and Commodity market.

(Sathiyamoorthy, 2015), primary data through a questionnaire observed that investors prefer to invest money in mutual funds for capital appreciation. According to her investment is a sacrifice of present value of money and allocating it in productive channels that balances the risk and reward. Bank deposits, fixed deposit, Provident fund, Mutual fund and Government securities are the most preferred choice of investors.

(Thakur S, \& Jain S, 2017), observed using z-test and $\mathrm{t}$-test house rental as the most preferred source of income, consecutively followed by Provisional Provident Fund, Employees Provident Fund however investors have also good perspective about Fixed Deposit as it is considered to be safest and most liquid form of investment where NPS is least preferred due to lack of awareness and knowledge.

(Jariwala H, 2013), observed the low literacy between the age group 18-35 that lead to misallocation of their wealth .Females are in need of financial education due to lack of financial awareness in decision making as they lag far behind when compared to developed countries. She suggested to have financial and money management as a part of school syllabus to be included since primary level. Every organization should play a dominant role in encouraging investment and savings of their employees.

\section{Investment Opportunities}

\subsection{Fixed Deposit}

Fixed deposits are the most conventional and preferred investment opportunity offers higher rate of interest than saving and recurring account. In this method a lump-sum amount is invested by investors for a fixed period of time at a certain rate of interest. There are certain commercial bank that offers tax-exemption on fixed deposit and even loans are granted at these deposits. The maturity period of fixed deposit ranges from 6 months to 10 years. It offers an opportunity for customer to withdraw money before maturity at an interest less than predetermined rate. Rate of interest offered by different banks vary based on maturity and entity of banks. In the current scenario there has been sharp decline in the interest rate offered by commercial banks particularly deposit of long tenure as these banks are in need of short duration fund to meet immediate expenditure. Fixed deposit offers an opportunity to gain compound interest by investing the earned income.

6.2 Mutual Fund-

Mutual fund is an investment vehicle wherein an asset management company or trust collect small savings of an individual and invest in a diversified portfolio like, equity, debt, bond, hybrid securities as per the demand of the investors. It works on the principle of capital appreciation and regular return by minimizing risk through diversification, registered under Securities Exchange Board of 
India. Mutual funds are of two types 1) Open ended mutual fund 2) Close ended Mutual fund. Open ended mutual funds can be purchased and sold at any period of time and offers liquidity to investors to make use of money during the time of need whereas close ended mutual fund are offered by company at a fixed period of time. Mutual fund offers tax benefit to investors through schemes like equity linked saving scheme as the funds invested are managed by well organized professionals offering a great deal of investment opportunities. As the mutual funds are regulated by government authorities even the medium salaried class is at ease that their earned income is under the purview of control.The unit in a mutual fund are valued at NAV, i.e., Net Asset Value .

\subsection{Public Provident Fund-}

Public Provident fund is the prominent tools in the hands in the hands of salaried class to earn tax free return through investment channel. The scheme was introduced by the Government of India and Ministry of Finance in the year 1968 for an individual in India. The maximum limit of investment is 1.5 lacks for any financial year in 12 installments and the interest granted by banks on public deposit is compounded annually on last day of every year. PPF is in operation for maximum of 15 financial years. However premature withdraw procedure is complicated in case of PPF as the money invested can be drawn only after sixth financial year under different circumstances, even loans can be availed by investors after third year. Interest on PPF is calculated on the lowest balance between fifth and the last day of the month (PPF Rules). The interest rate of 2018-2019 is as follows

Table 1: Showing interest rate on Public Provident Fund on Quarterly basis from April to September,2018-

\begin{tabular}{|c|c|}
\hline QUARTER & INTEREST RATE \\
\hline April- June 2018 & $7.6 \%$ \\
\hline July-September 2018 & $7.6 \%$ \\
\hline
\end{tabular}

6.4 Real Estate and Gold Investment-

Real estate is again a popular vehicle of investment for salaried employees in developing country like India where investments are made in form of land, buildings, house property, gold, silver and other valuable assets. In India real estate is of quite importance as it can be used to obtain loan and can be kept as a mortgage. Land is the only assets that do not get depreciated but its value always increases. Even the properties like gold and silver are considered to be the reserve of Indian women to be used during the contingencies converting into liquid form. Even today in rural India land are used against loan by unorganized money lender. Ownership of real estate gives the status in the society and enhances the standard of living. In the current scenario the public interest has shown a great decline in investment of real estate since demonetization due to cashless transaction and wipe out of unauthorized dealers from the market.
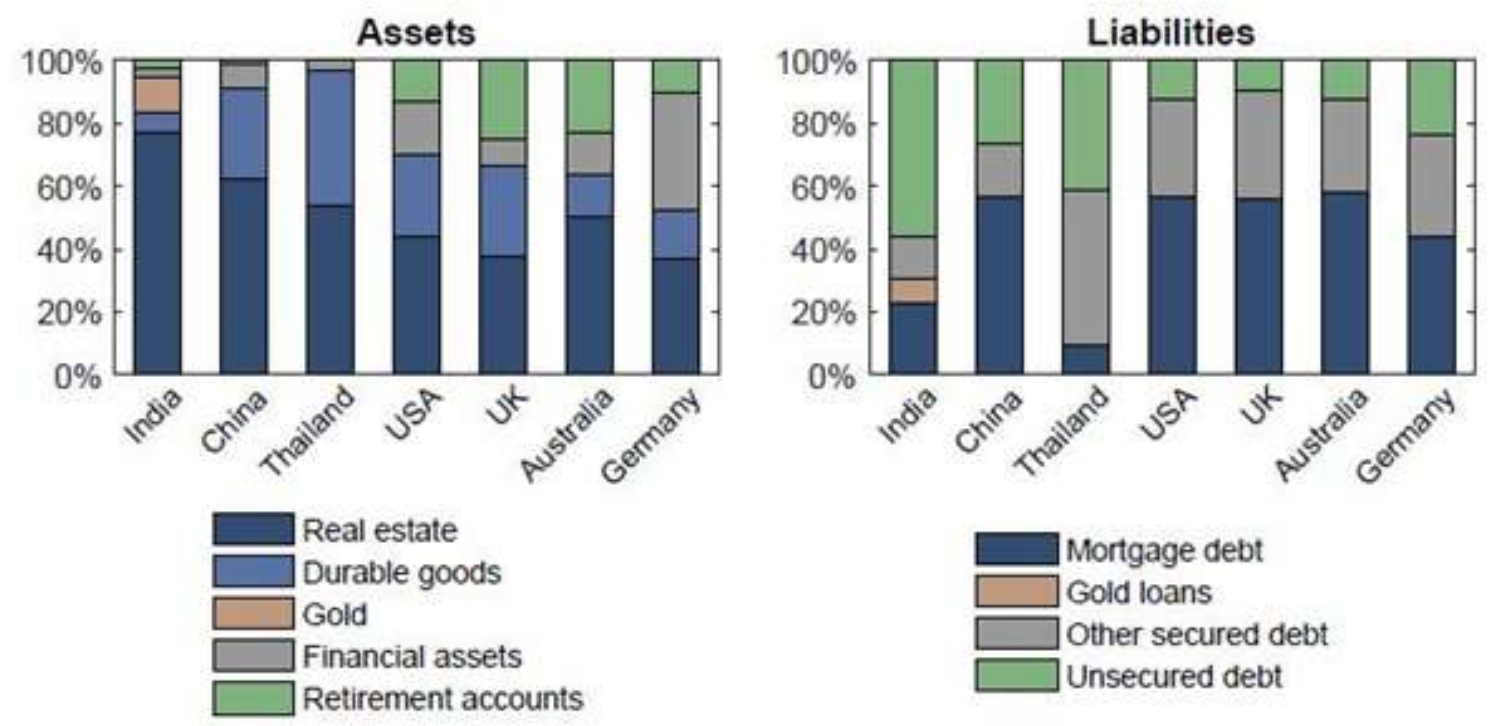

Fig 2- Participation in financial market along the life cycle

(Source: RBI, Report of the household finance Committee, 24 August, 2017) 
According to the report submitted by RBI on household finance committee, in India Gold play the dual role of investment and liabilities. About $77 \%$ of total assets are allocated in immovable property like land and building, plant and machinery, $7 \%$ of the total assets in durable goods like vehicles while 5\% in financial assets like marketable securities. When it comes to total liabilities in India major role is being played by unsecured debt while $23 \%$ of total liabilities are allocated in mortgage loan

\subsection{Life Insurance-}

Insurance is a contract between the two parties insurer and insured wherein insurer guarantee the insured to indemnify the loss in happening of a certain event. However the law of indemnity cannot be fulfilled in case of life insurance but it provides an opportunity to policyholders to live a peaceful life. The only motive behind every investment is to secure future and to meet any emergencies or to enhance standard of living. Life insurance is a conventional method of investment used to cover up the risk of life of family members and breadwinner. Nowadays it is a vehicle for investment to enhance financial security. There are number of scheme offered by the corporation that are availed by the policyholders at later stage of life to fulfill his dreams or used by the beneficiaries of policyholders. Another objective behind holding a policy is tax exemption, certain tax benefits are offered by scheme.

\subsection{Derivative Instrument-}

Derivative is the contract instrument value of which is derived from underlying assets. Futures, Forwards, Options are the derivative instruments that facilitate the transactions on future date at specified price to facilitate and hedge from speculative transactions. Derivative contract has gained a high significance in the present era due to uncertainties and high fluctuation in prices. Another opportunity of derivative market instrument is swap, where benefits from interest of financial instrument is exchanged between the parties .The greatest advantage of derivative instrument is that future transactions can be settled at current market price and to protect from speculation .

\subsection{Money market instrument-}

Money market instrument are the short term investing and financing facility available to investors for a period of one year. It includes commercial papers, certificate of deposits, t-bills, and more. Generally these instruments are issued at a discount by issuing company and redeemed at par, therefore investor gain the difference between issue and the redemption price. Due to shorter maturity period transaction cost charged is minimum as no stamp duty is required.

\subsection{Equity and debentures-}

Investment in equity and debentures are the most prominent and common vehicle to park high income group savings. Equity is the most risky form of investment as it includes the concept of more risk, more gain. Equity does not involve regular or certain return but in case a company is upward rising there is a high probability for investors to earn higher return. Generally the investments are opted by high income group who have extra income and are ready to take risk in long run as middle income group are risk averse and they avoid to take chance. On contrary to it debentures are the investment option that facilitate the regular return in form of interest and also provide high collateral security. People with defined income avoid to take risk and so they opt for investment as it is better option for regular return.

\section{Conclusion and Suggestions}

India being the fastest growing economy of the world, has tremendously developed the financial market since post independence. Even though Indian economy has faced the gradual movements in its structure since post independence from unorganized financial market to highly structure market, then to a globalization in the year 1991, trending to plastic money and now it comes about virtual transactions when we talk about crypto currency. A Well organized market has made the work easier for investors to transact through depository from their workplace through network connectivity .People are now able to update movements in investment prices at withhold minute details of their money. A lot has been developed still a more is required when compared to developed nation economy, India lags far behind in investment opportunities due to lack of financial literacy and awareness. The major component of any investment is to ensure safety, liquidity and tax relief and it is the sole responsibility of investor to be well aware of market condition of different securities to avail high return from investment in securities depending upon the need and opportunities.

\section{References}

[1] Gopi G, Priyanka D and Preetha R., An insight into the Saving and investment Pattern of Salaried employees working In Private sector of shipping industries at erakulam. International Journal of Pure 
and Applied Mathematics, Vol 118 (18) :1347-1363, (2018).

[2] Jain SC and Thakur. S,. Retirement Planning and Social security concept in Indian context.International Journal of Commerce and Management Reserach,Vol 3(2), 35-40,(2017).

[3] Jariwala H, To study the level of financial literacy and its impact on Investment decision An in-depth analysis of Investors in Gujrat. V. M. Patel Institute of Management Ganpat University, Ganpat Vidyanagar Mehsana-Gozaria Highway, Mehsana-384012 Gujarat,India. gujrat,(2013) .

[4] Public Provident Fund Rules: (Pdf), (n .d). Retrieved https://www.dacollege.org>PPFRULES

[5] Rajora V. (2010). Applicability of Minimum Wages Act and Payment of Gratuity Act to teachers: An Analysis
ISSN 2455-6378

.Retrieved from https://papers.ssrn.com>Delivery.cfm

[6] RBI (2017), Report of the household finance Committee, 24 August, 2017 Retrieved from http://www.rbi.org.in/SCRIPTS/Publicatio $\mathrm{n}$ Report of household Finance Committee.

[7] Sathiyamoorthy, M. C ,Investment Pattern and Awareness of Salaried Class investor in Tiruvanamalai district of Tamil Nadu. Asia Pacific Journal of Research , 75-83 (2015).

[8] Shekhar R, Employee benefits in India: An Introduction , CFA ,IFCAI , Milliman White Paper: (2013)

[9] Thomas, R. S. (2014, July). The way forward for India's National Pension System. Mumbai Indira Gandhi Institute of Development Research.Retrieved fromhttp://www.igidr.ac.in/pdf/publicatio ns/WP-2014-022.pdf. 